\title{
THE PROTECTIVE EFFECT OF SARANG SEMUT (Myrmecodia tuberose) TUBERS INFUSION ON GENTAMICIN-PIROXICAM INDUCED NEPHROTOXICITY IN RATS
}

\author{
Tanti Azizah Sujono*, Rima Munawaroh, Peppy Kumala Wijayanti, \\ Yuyun Puji Lestari
}

Faculty of Pharmacy, Muhammadiyah University of Surakarta

Jl. A. Yani Tromol Pos 1 Pabelan Kartasura Surakarta Jawa Tengah 57162 Indonesia

Submitted: 23-12-2013

Revised: 28-01-2014

Accepted: 15-03-2014

*Corresponding author

Tanti Azizah Sujono

Email :

tantiums@yahoo.com

\begin{abstract}
Kidney is very important organ for blood filtration. Impaired renal function often results in chronic kidney disease. Sarang semut (Myrmecodia tuberosa) is traditionally used to cure various diseases. This research was conducted to determine the effect of sarang semut infusion in nephrotoxicity rats models by gentamicin-piroxicam. Thirty male Wistar rats were divided into 6 groups. Group I as normal control (CMC Na was treated orally for 7 days), group II was treated sarang semut infusion dose of $1 \mathrm{~g} / \mathrm{kgBW}$ orally for 7 days, group III as nephrotoxic control was injected by gentamicin $100 \mathrm{mg} / \mathrm{kgBW}$ intraperitoneally and piroxicam $3.6 \mathrm{mg} / \mathrm{kgBW}$ orally daily for 7 days and group IV until VI were rats simultaneously treated with sarang semut infusion at the dose of 1,2 , and $4 \mathrm{~g} / \mathrm{kgBW}$, respectively and induced by gentamicin-piroxicam daily for 7 days. Parameters of kidney function such as serum creatinine and blood urea nitrogen (BUN) levels were measured on day 0 and 7 using spectrophotometer. The rats were then sacrificed, kidneys tissue were removed for examination of renal index and kidney histology. These results showed that sarang semut tubers infusion at the dose of 1,2 , and $4 \mathrm{~g} / \mathrm{kgBW}$ reduced BUN and creatinine levels on induced-nephrotoxic rats. Creatinine level was reduced significantly to $1.76 \pm 0.13 ; 0.86 \pm 0.15$; $0.60 \pm 0.07 \mathrm{mg} / \mathrm{dL}$, respectively. The creatinine level of nephrotoxic control was $5.16 \pm 0.27 \mathrm{mg} / \mathrm{dL}$. BU level decreased significantly to $55.66 \pm 6.22 ; 18.49 \pm 2.61 ; 16.81 \pm 1.24 \mathrm{mg} / \mathrm{dL}$, respectively. Meanwhile the BUN level of nephrotoxic control was $276.65 \pm 50.52 \mathrm{mg} / \mathrm{dL}$. Rat histological profile of the three doses tratment showed improvement in renal cell after administration of sarang semut infusion for 7 days.
\end{abstract}

Key words: Myrmecodia tuberosa, blood urea nitrogen, creatinine, gentamicin-piroxicam

\section{INTRODUCTION}

Kidney is very important organ particularly for filtering blood to discard unnecessary substances. The kidney showed many essential functions in the body such as remove waste products of metabolisms, maintain fluid and electrolyte balances and also the homeostasis system (Kelly, 2004). Impaired kidney function often result in Chronic Kidney Disease (Dowling, 2005).

Chronic renal failure is a serious problem in the world, in both developed and developing countries, which currently increased substantially. From a survey conducted by
PERNEFRI (Association Nephrology Indonesia) in 2009, the prevalence of chronic renal failure in Indonesia approximately $12.5 \%$ which means that there are 18 million adults in Indonesia suffered from chronic renal failure (PERNEFRI, 2009).

Gentamicin is an aminoglycoside antibiotic widely used in treating severe Gram negative bacterial infection. The clinical use is limited due to nephrotoxicity effect. There are some evidence indicate that free radical are important mediators of gentamicin toxicity. Gentamicin may induce the formation mechanism of reactive oxygen species (free radicals) 
(Sukandar et al., 2011). More severe renal damage can be induced by a combination of NSAIDs (Non Steroid Antiinflammation Drugs) and nephrotoxic drugs (Hosaka et al., 2004).

Renal replacement therapy such as dialysis and kidney transplantation, as well as erythropoietin therapy can inhibit the increased of the disease severity, but requires an expensive cost. Therefore, it is needed to explore agents capable to inhibit the progression of chronic renal failure, which is safe and inexpensive, because kidney disease is a chronic disease that requires longterm treatment (Yokozawa et al., 2002)

Sarang semut contains several chemical compounds such as flavonoids, tannins, and polyphenols having antioxidant activity. Moreover, since the extract of sarang semut capable to inhibit the activity of xanthine oxidase and uric acid, this migth improve renal function (Simanjuntak et al., 2010). AbdelRaheem (2009) proved that the flavonoid quercetin has a protective effect in gentamicininduced nephrotoxic rats. The flavonoid compounds identified in sarang semut, were kaempferol, luteoline, rutin, quercetin and apigenin (Engida, et al., 2013). Therefore, it was necessary to do research on the protective effects of sarang semut infusion in gentamicinpiroxicam - induced kidney damaged rats.

\section{MATERIAL AND METHODS}

Sarang semut tuber (UD. Fira Papua), gentamicin injection (PT. Indofarma), piroxicam capsul (PT. Sampharindo Perdana), reagent kit urea FS* (DiaSys Diagnostic System GmbH cat. 131019910021), Creatinine FS* (DiaSys Diagnostic System GmbH cat. 117119910021), distilled water, $\mathrm{CMC} \mathrm{Na}$, and formalin $10 \%$.

\section{Animal testing}

Healthy Wistar male rats (from Faculty of Pharmacy Gadjah Mada University), aged 23 months, weight 150-250g.

\section{Experimental prosedure}

\section{Making infusion of sarang semut}

Sarang semut infusion was made with concentrations of $8 ; 16$ and $32 \% \mathrm{w} / \mathrm{v}$. Dried sarang semut each weighed $8 ; 16$ and $32 \mathrm{~g}$, were put in different infusion pans. Water as much as 2 times the weight of dried sarang semut was added to tend the dried material. After addition of $100 \mathrm{~mL}$ water the mixture was then heated for $15 \mathrm{~min}$ at $90^{\circ} \mathrm{C}$ on waterbath, while stirred occasionally. The mixture was filtered, while still hot, with flannel. Additional hot water was poured through the dregs to obtained desire volume. The infusion was administered to the rats with volume of $2.5 \mathrm{~mL} / 200 \mathrm{gBW}$ (equal with the dose of $1 ; 2$; and $4 \mathrm{~g} / \mathrm{kgBW}$, respectively)

\section{Induction nephrotoxic in rats}

Induction of nephrotoxic in rats were carried out using gentamicin $100 \mathrm{mg} / \mathrm{kgBW}$ (i.p) and piroxicam $3.6 \mathrm{mg} / \mathrm{kgBW}$ (p.o) (Sukandar, et.al., 2011). Eventually, $100 \mathrm{mg} / \mathrm{kgBW}$ gentamicin was injected intraperitoneally (i.p) daily during 7 days whereas piroxicam $3.6 \mathrm{mg} / \mathrm{kg}$ BW was given peroral (p.o) daily for 7days. Rats was considered to be nephrotoxic if blood urea nitrogen (BUN) and creatinine levels increased significantly compared to that of the control group.

\section{Nephroprotective test}

Thirty rats were divided into six treatment groups. Each group consisted of five rats. Group I as normal control (CMC Na was administered orally for 7days); group II was treated with sarang semut infusion at the dose of $1 \mathrm{~g} / \mathrm{kgBW}$ orally for 7 days; group III as nephrotoxic control was injected with gentamicin $100 \mathrm{mg} / \mathrm{kgBW}$ intraperitoneally and piroxicam $3.6 \mathrm{mg} / \mathrm{kgBW}$ orally daily for 7 days; group IV until VI, were rats simultaneously treated with sarang semut infusion at doses of 1,2 , and $4 \mathrm{~g} / \mathrm{kgBW}$, respectively, and induced by gentamicin-piroxicam daily for 7 days. Blood was taken from the lateral tail vein on day 0 and 7 for measuring serum creatinine and BUN levels. Later in the day 7, rats were sacrificed and the kidney were taken for determination of renal index and histological evaluation.

\section{Determination of renal index}

Renal index is calculated by comparing the kidney weight to body weight of rats.

\section{Determination of BUN level}

BUN level was determined using urea FS* (DiaSys) kit reagent. BUN level was measured with UV spectrophotometer at the wavelength $(\lambda)$ of $340 \mathrm{~nm}$. 
BUN levels $(\mathrm{mg} / \mathrm{dL})=$ concentration of urea $(\mathrm{mg} / \mathrm{dL})$ x conversion factor $(0.467)$.

\section{Determination of serum creatinine level}

Serum creatinine level was determined using creatinine FS* (DiaSys) kit reagent. It was measured with spectrophotometer at the wavelength $(\lambda)$ of $546 \mathrm{~nm}$.

\section{Statistical analysis}

Data of BUN and creatinine levels were analyzed by one way ANOVA test followed by post-hoc LSD (Least Significant Difference) with $95 \%$ confidence level using the SPSS program.

\section{RESULTS AND DISCUSSION}

Effect of sarang semut infusion on renal function improvement in gentamicinpiroxicam induced nephrotoxicity rats

Sarang semut tubers infusion have effect on the improvement of renal function in gentamicin-induced renal piroxicam using parameters of serum creatinine, Blood Urea Nitrogen (BUN) blood level, renal index and histology of kidney. The higher levels of creatinine and urea in the blood indicating reduction of kidney function.

The normal value of creatinine in blood is less than $1.2 \mathrm{mg} / \mathrm{dL}$. On day 0 (base line), all groups showed the serum creatinine level in normal range, it mean that the serum creatinine on day 7 increase due to the treatment. Group III as nephrotoxic control which was only induced by gentamicin and piroxicam (GP) showed an increase serum creatinine level approximately 11 times compared to that of normal values on day $0(0.46 \pm 0.09) \mathrm{mg} / \mathrm{dL}$ become $(5.16 \pm 0.27) \mathrm{mg} / \mathrm{dL}$ on day 7 (Figure 1).

Serum creatinine on day 7 in control CMC Na group and sarang semut infusion groups, with the dose of $1 \mathrm{~g} / \mathrm{kgBW} ; 2 \mathrm{~g} / \mathrm{kgBW}$; and $4 \mathrm{~g} / \mathrm{kgBW}$, showed significance different to nephrotoxic control which was only induced by gentamicin-piroxicam (GP) $(\mathrm{p}<0.05)$. This result showed that the treatment of sarang semut infusion for 7 days could decrease the creatinine level, but only sarang semut infusion at dose of 2 and $4 \mathrm{~g} / \mathrm{kgBW}$ that showed no significant differences $(p>0,05)$ compared to that of normal control group. This mean that sarang semut infusion at doses of 2 and
$4 \mathrm{~g} / \mathrm{kgBW}$ could reduce serum creatinine back to normal level. On the other hand based on Pearson test correlation indicated that among the treatment of sarang semut infusion at doses of 1,2 and $4 \mathrm{~g} / \mathrm{kgBW}$, there are significant differences $(\mathrm{p}<0.05)$ with Pearson correlation 0.930 (strength of the correlation is very strong). This gave information there are a dose dependent trend of sarang semut infusion in lowering serum creatinine.

The normal value of blood urea nitrogen (BUN) is $8-25 \mathrm{mg} / \mathrm{dL}$. On day 0 (base line), all groups showed the BUN in normal range, indicating that the increased of BUN on day 7 due to the treatment. Group III, as nephrotoxic control, demonstrated an increase of BUN level approximately 13times, from $(21.16 \pm 2.00)$ on day 0 to $(276.65 \pm 50.52) \mathrm{mg} / \mathrm{dL}$ on day 7 (Figure 2). Blood Urea Nitrogen (BUN) in control CMC Na group and treatment groups of sarang semut infusion at doses of $1 ; 2$; and $4 \mathrm{~g} / \mathrm{kgBW}$ showed significance different with nephrotoxic control $(\mathrm{p}<0.05)$. This result indicated that sarang semut infusion could decrease BUN level. However, only sarang semut infusion at the doses of 2 and $4 \mathrm{~g} / \mathrm{kgBW}$ that showed no significant difference $(p>0,05)$ compared to that of normal control group. The result indicated that sarang semut infusion at doses of 2 and $4 \mathrm{~g} / \mathrm{kgBW}$ could reduce BUN to normal level. Meanwhile, between the treatment infusion $2 \mathrm{~g} / \mathrm{kgBW}$ and $4 \mathrm{~g} / \mathrm{kgBW}$ showed no significant difference $(\mathrm{p}>0.05)$, meaning that the effect of lowering BUN at dose of 2 and $4 \mathrm{~g} / \mathrm{kgBW}$ were equivalent. Meanwhile according to the Pearson test correlation demonstrated that among the treatment of sarang semut infusion at doses of 1,2 and $4 \mathrm{~g} / \mathrm{kgBW}$, there are significant difference $(p<0.05)$ with Pearson correlation 0.868 (strength of the correlation is very strong). This indicated that there were a dose dependent trend of sarang semut infusion in decreasing BUN.

The administration sarang semut infusion alone to rats for 7 days did not exhibit any significant change in BUN and serum creatinine parameters (Figure 1 and 2).

Sarang semut infusion was also capable to reduce renal index. The nephrotoxic control showed the highest renal index among the 


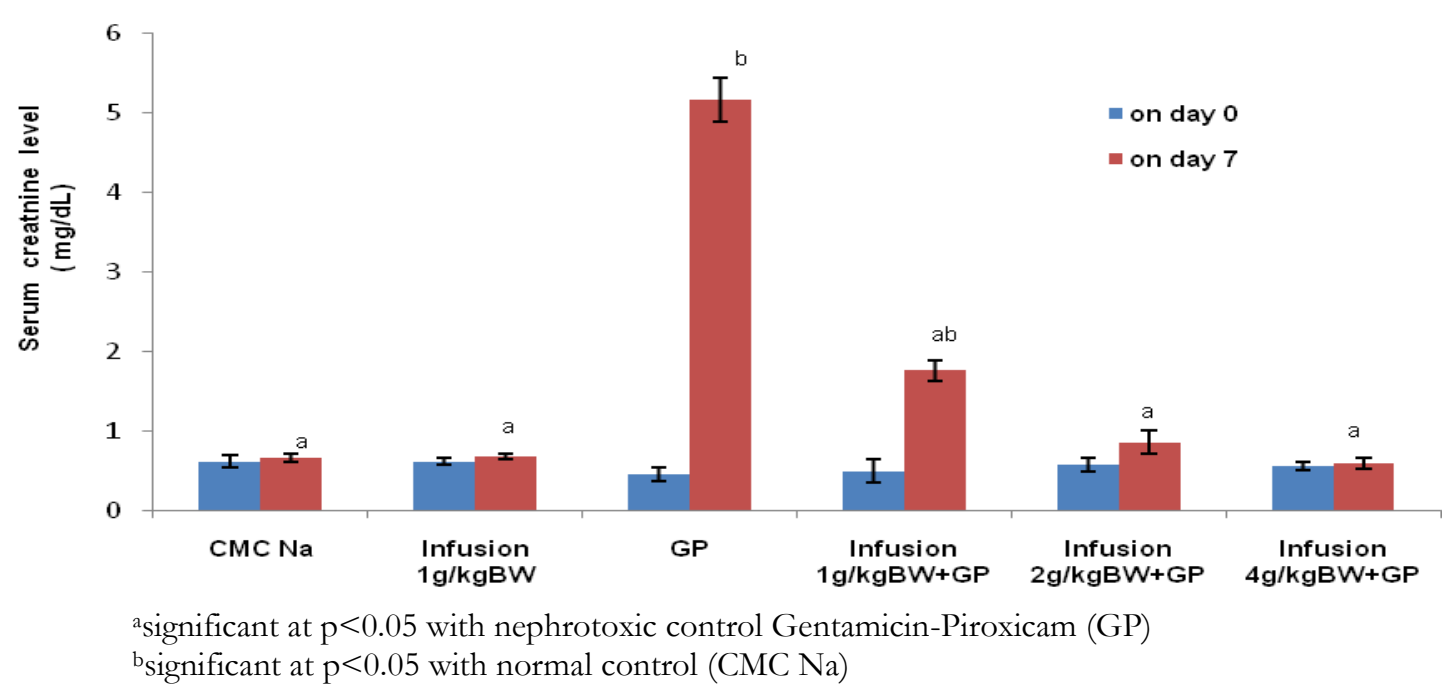

Figure 1. Serum creatinine (mean $\pm \mathrm{SD}$ ) on day 0 and after treatment of sarang semut infusion for 7 days in induced by gentamicin-piroxicam rats $(\mathrm{GP})(\mathrm{n}=5)$.

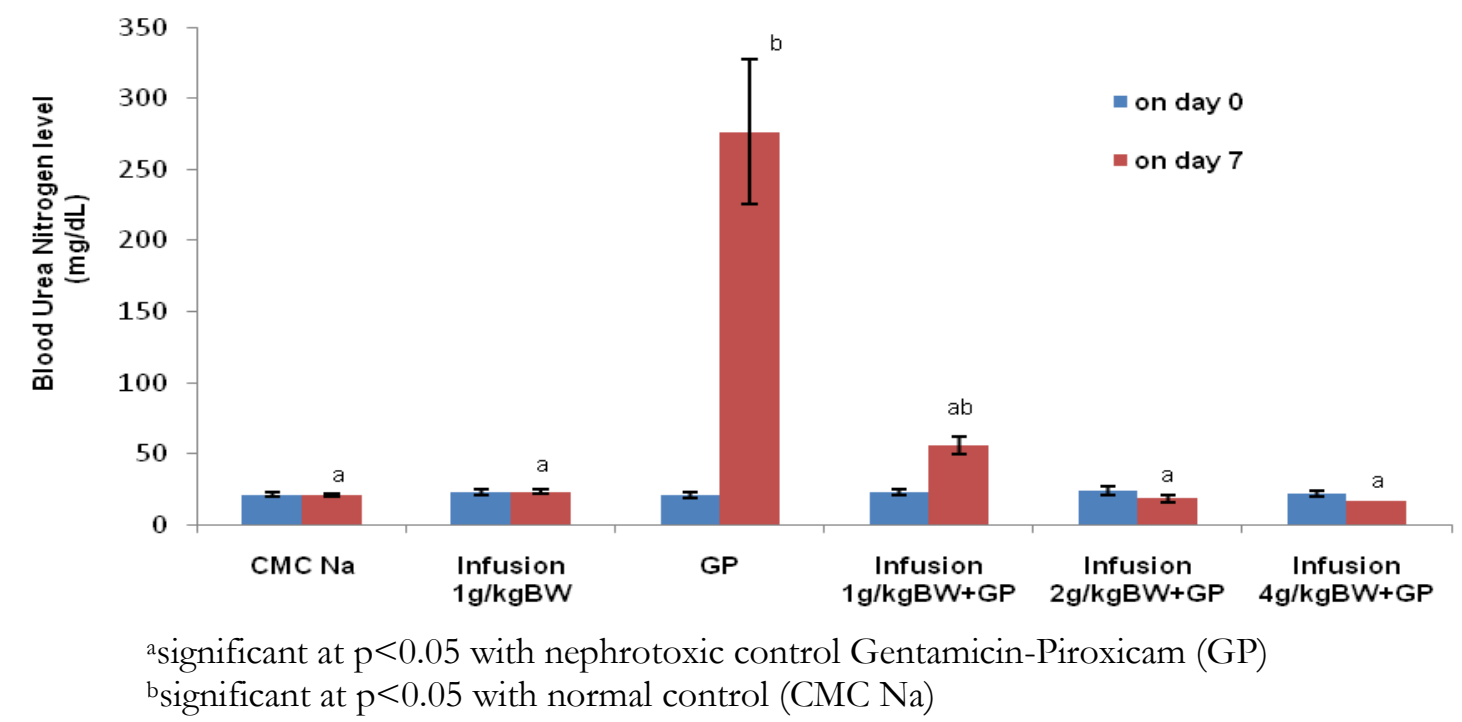

Figure 2. Level of BUN (mean \pm SD) on day 0 and after treatment of sarang semut infusion for 7 days in induced by gentamicin-piroxicam rats $(\mathrm{GP})(\mathrm{n}=5)$.

other groups and significantly different from the treated infusion dose of 1,2 and $4 \mathrm{~g} / \mathrm{kgBW}$ $(\mathrm{p}<0.05)$ (Figure 3).

\section{Histology of kidney}

Histological examination revealed that in nephrotoxic group (Figure 4b) (induced by gentamicin-piroxicam only), showing nephrosis characterized by eosinophilic homogeneous mass in the lumen of the tubular part, partly tubular epithelial degeneration and necrosis. On the other hand in Figure $4 \mathrm{c}$ and $4 \mathrm{~d}$ the damaged of glomeruli and tubuli could return to normal or similar to normal control (Figure 4a).

The induction of kidney damage using gentamicin is one of the most common methods used at present time. Gentamicin is an aminoglycoside antibiotics which have side effects such as nephrotoxic. Mechanism of nephrotoxicity probably is caused by the formation of Radical Oxygen Species (ROS) 


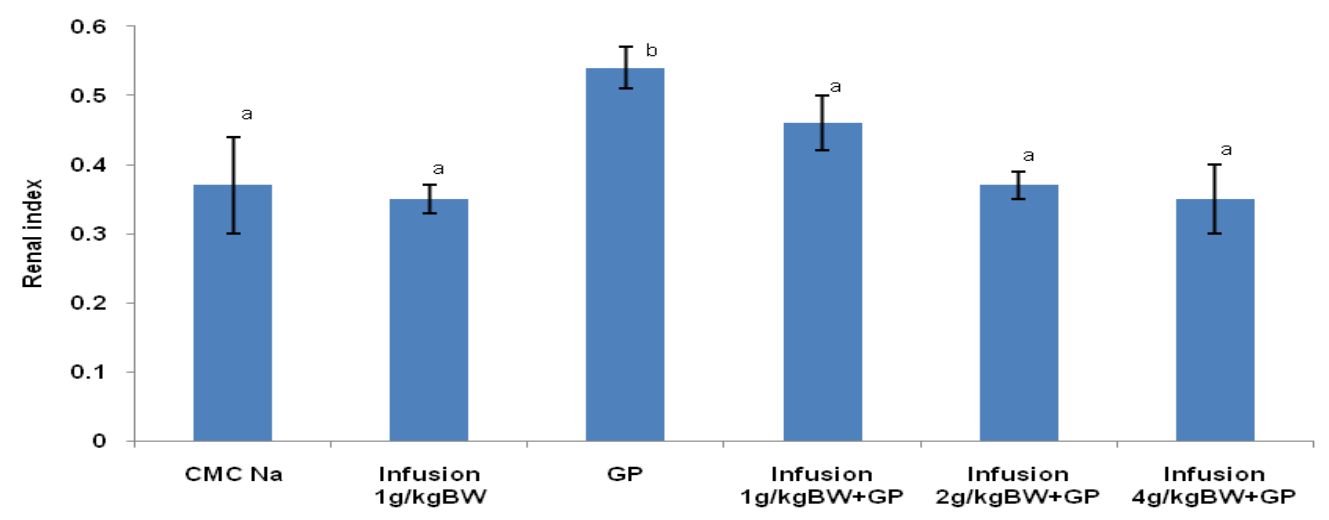

asignificant at $\mathrm{p}<0.05$ with nephrotoxic control Gentamicin-Piroxicam (GP)

bsignificant at $\mathrm{p}<0.05$ with normal control $(\mathrm{CMC} \mathrm{Na})$

Figure 3. The effect of sarang semut infusion on renal index profile (Mean $\pm S D)(n=4)$

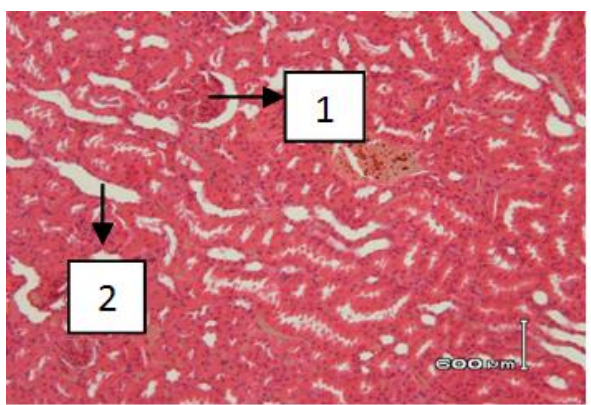

a. Normal Control

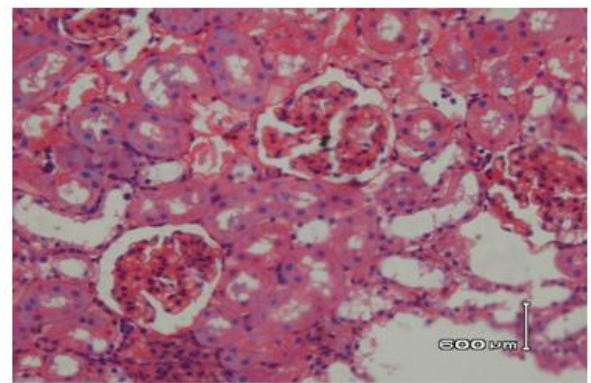

c. treatment of sarang semut infusion $1 \mathrm{~g} / \mathrm{kgBW}$

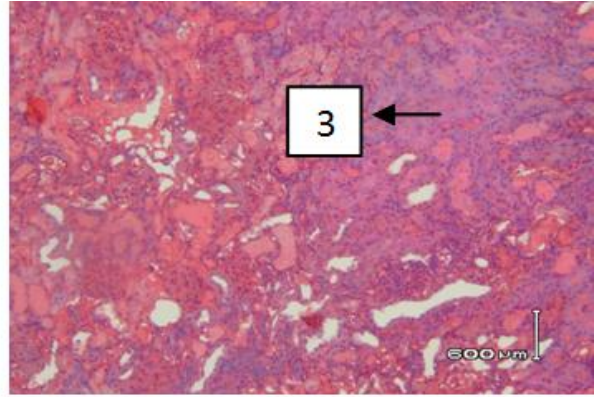

b. Nephrotoxic Control

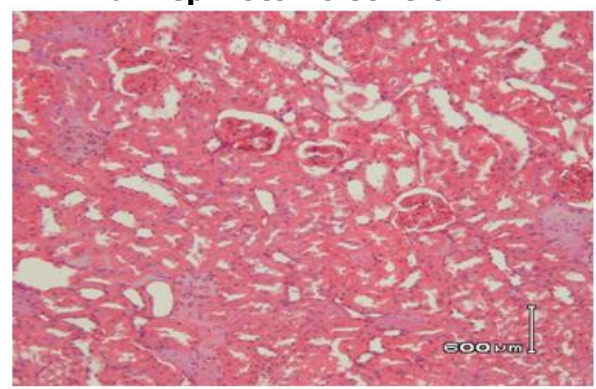

d. treatment of sarang semut infusion 4g / kgBW

Figure 4. Kidney's histology with hematoxilin and Eosin staining. (1) normal glomeruli, (2) normal tubuli, (3) nephrosis (indicated by eosinophilic homogeneous mass in the lumen of the tubular part, partly tubular epithelial degeneration and necrosis

and nitrosative which induce nephrotoxic. It is shown that $\mathrm{O}_{2} \bullet, \mathrm{OH}$ and $\mathrm{H}_{2} \mathrm{O}_{2}$ are involved in the renal damage induced by gentamicin (Petronilho et al., 2009; Poormoosavi et al, 2010).

The significant increase in lipid peroxide (TBARS) levels and decrease in glutathione
(GSH) levels, superoxide dismutase (SOD) and catalase (CAT) activities, showed that gentamicin induced nephrotoxicity was mediated through oxidative stress reactions (Abdel-Raheem et al., 2009). Gentamicin causes an increase in the concentration of biochemical renal function such as serum urea and 
creatinine along with the total protein excreted in the urine (Abdel-Raheem et al., 2010). These changes lead to nephrotoxic as evidenced by the decrease in glomerular filtration rate (GFR) (Ozbek, et al., 2009).

Other drugs that having toxic effects on the kidney were the class of NSAIDs (Non Streroid Anti-Inflammation Drugs) such as piroxicam. The toxic effects were associated with the inhibition of prostaglandin causing imbalance compensation in the form vasodilatory leading to the damage of glomerular filtration rate (Hosaka et al., 2004)

Previous studies have shown that Myrmecodia pendan, which have similar genus to Myrmecodia tuberosa, contain flavonoids. The flavonoid compounds identified were kaempferol, luteoline, rutin, quercetin and apigenin (Engida et al., 2013). Flavonoids have benefits for corresponding plants and humans who consume them. Flavonoids contained in the sarang semut infusion are suspected as an antioxidant that can neutralize Reactive Oxygen Species (ROS) which are formed from induction gentamicin. Flavonoids content in the sarang semut infusion persumably was polar flavonoid, rutin. Rutin is a glycoside flavonoid widely distributed in plant kingdom and contains quercetin as its aglycon part and rutinose as glycon part (Sreedevi et al., 2010). The previous study showed that rutin worked as an antioxidant in vivo by scavenging ROS. This property migth serves to prevent oxidative renal damage in rat treated with potassium bromate (Khan et al., 2012). Rutin have also shown protective and beneficial effects on gentamycin induced oxidative stress in rats (Akondi et al., 2011). Beside that, in other research showed that simultaneously administration of quercetin and gentamicin protected kidney tissues against nephrotoxic effects of gentamicin, as proved from improvement of histopathological profile and normalization of kidney biochemical parameters such as creatinine and BUN (AbdelRaheem et al., 2009)

Another study proved that sarang semut showed other biological activity such as an immunomodulator (Hertiani et al., 2010). Sarang semut water extract showed anticancer activity on HeLa cells and MCM-B2 greater than that of non-polar extract (Soeksmanto et al., 2010), water extract also has antioxidant and cytotoxic activity with $\mathrm{IC}_{50}$ of $30.66 \mathrm{mg} / \mathrm{mL}$ (Bustanussalam, 2010).

The data of this research showed that the sarang semut infusion at dose of 1,2 and $4 \mathrm{~g} / \mathrm{kgBW}$ had the nephroprotective effects. They could reduce the level of BUN and serum creatinine compare to the nephrotoxic control group $(p<0.05)$. However, at dose of $1 \mathrm{~g} / \mathrm{kgBW}$, the decline did not return to normal values. Meanwhile, sarang semut infusion at doses of 2 and $4 \mathrm{~g} / \mathrm{kgBW}$ could prevent impaired kidney function characterized by the return of BUN and creatinine levels decreased to normal levels as before the nephrotoxic induction by gentamicin-piroxicam.

\section{CONCLUSION}

Sarang semut tuber infusion at doses of 1,2 , and $4 \mathrm{~g} / \mathrm{kgBW}$ could improve the kidney function of rats based on parameters of BUN, creatinine blood levels, renal index and histopathology of kidney in rats inducednephrotoxic by gentamicin-piroxicam.

\section{ACKNOWLEDGMENTS}

This Research was supported by LPPM UMS regular competitive research grant 2012

\section{REFERENCES}

Abdel-Raheem IT., Abdel-Ghany AA., Mohamed GA., 2009, Protective Effect of Quercetin against GentamicinInduced Nephrotoxicity in Rats, Biol. Pharm. Bull, 32

Abdel-Raheem IT., El-Sherbiny GA., Taye A., 2010, Green Tea Ameliorates Renal Oxidative Damage Induced by Gentamicin in Rats, J. Pharm Sci, 23, 2128

Akondi RB., Akula A., Challa SR., 2011, Protective Effects of Rutin and Naringin on Gentamicin Induced Testicular Oxidative Stress, Eur J Gen Med, 8 (1): 57-64

Bustanussalam, 2010, Penentuan Struktur Molekul dari Fraksi Air Tumbuhan Sarang Semut Myrmecodia pendens Merr \& Perry yang Mempunyai Aktivitas Sitotoksik dan Sebagai Antioksidan, Thesis, Sekolah Pascasarjana, IPB Bogor 
Dowling TC., 2005, Renal Disorders, dalam Pharmacotherapy a Pathophsiologic Approach Edisi 7, Dipiro, JT., Talbert, RL., Yee, GC., et al., 705 - 835, The McGraw Hill Companies Inc, New York.

Engida AM., Kasim NS., Tsigie YA., Ismadji S., Huynh LH, Yi-Hsu Ju., 2013, Extraction, Identification and Quantitative HPLC Analysis of Flavonoids from Sarang Semut (Myrmecodia pendan), Industrial Crops and Product, Volume 41: 392-396

Hertiani T., Sasmito E., Sumardi, Ulfah M., 2010, Preliminary Study on Immunomodulatory Effect of Sarang Semut Tubers Myrmecodia tuberose and Myrmecodia pendens, OnLine J.Bio. Sci.10 (3) : 136-141

Hosaka EM., Santos OF., Seguro AC., Vattimo MF., 2004, Effect Of Cyclooxigenase Inhibitor on Gentamicin - Induced Nephrotoxicity in Rats, Braz J Med Biol Res, 37: 979 - 985

Kelly L., 2004, Essentials of Human Physiology for Pharmacy, CRC Press, Florida, USA, pp 308

Khan RA., Khan MR., and Sahreen S., 2012, Protective Effect of Rutin againts Potassium Bromate Induced Nephrotoxicity in Rats, Research Article, BMC Compleentary and Alternative Medicine, 12: 204

Ozbek E., Cekmen M., Ilbey YO., Simsek A., Polat EC., Somay A., 2009, Atorvastatin Prevents Gentamicin-Induced Renal Damage in Rats Though the Inhibition of p38-MAPK and NF-kB Pathways. Renal Failure, 31 : 382-392

PERNEFRI, 2009, Annual Meeting 2009, Perhimpunan Nefrologi Indonesia. http://www.kalbe.co.id
Petronilho FL., Constantino B., de Souza A., Reinke, Martins MR, 2009, Efficacy of the Combination of $\mathrm{N}$-acetylcysteine and Desferrioxamine in the Prevention and Treatment of Gentamicin-induced Acute Renal Failure in Male Wistar Rats. Nephrol. Dial. Transplant, 24 :2077-2082

Poormoosavi SM., Behmanesh MA., Najafzadeh H., 2010, Effect of cimetidin on Gentamicin-Losartan induced Neprhotoxicity in Rats, Af. J. P. Pharmacology 4(6), 341 - 345.

Simanjuntak P., Fanny, Subroto MA., 2010, Isolasi Senyawa Aktif dari Ekstrak Hipokotil Sarang Semut (Myrmecodia pendens Merr, \& Perry) Sebagai Penghambat Xantin oksidase, Jurnal Ilmu Kefarmasian Indonesia, 49 - 54

Soeksmanto A., Subroto MA., Wijaya H., Simanjuntak P., 2010, Anticancer Activity Test for Extracts of Sarang Semut Plant (Myrmecodya pendens) to Hela and MCMB2 Cells, Pakistan J.Bio. Sci., 13 (3)

Sreedevi A., Bharathi K., Prasad KVSRG., 2010, Protective Effect of Rutin against Cisplatin-Induced Nehprotoxicity in Rats, J.Nat. Remedies, 10 (2) : 144-151

Sukandar EY., Fidrianny I., Adiwibowo LF., 2011, Efficacy of Etanol Extract of Anredera cordifolia (Ten) Steensis Leaves on Improving Kidney Failure In Rats, Int. J. Pharmacology, 7 (8), $850-855$.

Yokozawa T., Kim HY., Nonaka GI., Kosuna K., 2002, Buckwheat Extract Inhibits Progression of Renal Failure, $J$. Agric.Food Chem., 50 